\title{
The world Islamic sciences and education university students' attitudes towards the inclusion of handicapped students within campus main stream
}

\author{
Esam Abdullah Al Jaddou \\ Department of Special Education, Faculty of Educational Sciences, the World Islamic Science and Education University \\ W.I.S.E, Jordan. \\ Received 21 March, 2018; Accepted 14 May, 2018
}

\begin{abstract}
This study aims to examine the World Islamic Sciences and Education University students' attitude toward the inclusion of handicapped students within the university environment. The sample of the study consists of $\mathbf{2 4 7}$ male and female undergraduate students of the World Islamic and Education University at the academic year 2017/2018. To achieve the objectives of the study, a valid and reliable scale of World Islamic University students' attitudes toward special needs students' inclusion in campus was prepared and applied. The data analysis revealed that the level of the attitudes of World Islamic University students toward handicapped students' inclusion within campus was medium. The study findings revealed that there was a statistically significant difference in the participants' attitudes toward the handicapped inclusion in the mainstream of World Islamic University based on gender in favor of male students; and there were statistically significant differences based on academic level in favor of third and fourth year students regarding the inclusion of handicapped in the mainstream campus. In addition, there is a statistically significant difference in students' attitudes based on faculty variable. The study findings revealed there are no statistically significant differences in students' attitude based on social status variable.
\end{abstract}

Key words: College students' attitude, inclusion, handicapped.

\section{INTRODUCTION}

Modern educational trends and practices emphasize the right of handicapped students to receive education at different levels based on the principle of they having equal opportunity with normal students, despite the individual differences between them.

As a result, inclusion has become a common and wide spread educational practice that meets the needs of these handicapped students. International laws have affirmed the right of equality and justice for people with disabilities. Examples of this are Education for All Act, which was raised by United Nations Educational, Scientific and Cultural Organisation (UNESCO).

The laws which have been enacted by many countries around the world have played a role in increasing the interest in higher education for handicapped students and increasing the number of handicapped persons enrolled in universities (Healey et al., 2006). In the United States, for example, Article 504 of the Rehabilitation Act of 1973

E-mail: aalb2255@yahoo.com.

Author(s) agree that this article remain permanently open access under the terms of the Creative Commons Attribution License 4.0 International License 
and the Americans handicapped Act (ADA) in 1990 provided formally for the full rights of handicapped students to study in universities and higher institutions (Cook et al., 2009).

However, the application of the aforementioned acts may lead to a clash to the extent of accepting individuals and their attitudes towards higher education along with their level of success or failure. Therefore, the issue of attitudes and study have become one of the most important issues in handicapped education. This is because the success of any attitude that seeks to integrate handicapped people into mainstream environment is influenced by the attitudes of normal individuals towards handicapped which may be either negative or positive. Thus, negative attitude towards such students is the most serious obstacles to the handicapped progress in all fields. This negative attitude has its roots deep in history; it extends far back to the days of the Greeks and Romans. It has been isolated or eradicated; also negative names are used for them and they are deprived of their basic rights (Baker et al., 2012).

In this regard, Maggiolini and Molteni (2013) confirm that handicapped students in universities are stigmatized and stereotyped; such students are subjected to vulnerability, illness, compassion, and normal students feel discomfort, anxiety and depression when they are around them.

Baker et al. (2012) argue that some of the problems that hinder the process of educating handicapped people are those problems in universities that are in the form of stereotypical thinking of students and teachers towards this class of students. This type of thinking is accompanied by the negative attitudes and low expectations of their performance, lack of knowledge of their needs and the sensitivity of meeting those needs.

The concepts of attitudes vary and come in different types. Cooper and Haney (1999) have defined attitude as the tendency of individual to behave either in a positive or negative way towards something, which may be a person, group or idea. Wade and Tavris (2005) define attitude as the tendency to respond to something; it is not a behavior, rather a condition that takes place before behavior. Al Makhzoumi (2001) points out in this regard, attitude is a state of mental or cognitive situation or a stand that a person develops towards a certain thing or a given subject whether by acceptance, rejection or being neutral. Sultan (2003) sees attitude as a complex mental and cognitive process which tends to relatively and steadily tilts toward things or individuals.

Anderson (2005) points out to attitude as what individual expresses in orderly and coherent manner that is characterized by consistency and sustainability. Abdullah (2007) stated that the three-way attitude consists of a cognitive component that includes the information and beliefs acquired by the individual towards the subject of direction, an emotional component related to an individual's impact on the subject of direction, and a behavioral component that reflects the behavior of an individual towards the subject of direction. And this is what drives the individual to act in a certain way when confronted with the subject of this attitude, and that attitudes are acquired and not inherited.

Attitudes are categorized into three forms: Positive attitudes are acceptance of the individual; negative attitude is the rejection of something and neutral attitude is the difference in the position of the individual between acceptance or rejection; attitudes vary in intensity and weakness (Nassar and Hassan, 2007). Al-Khatib and AlHadidi (2011) believe that the idea of handicapped students' inclusion within ordinary students is the result of various factors: first, the handicapped students need to obtain their right to education, the second is the difficulty of providing special institutions for handicapped students, the third is the result of positive inclusion, whether economic, educational, psychological or social, both for an individual or a community.

Hassan (2017) saw that inclusion helps in fulfilling equivalent education to all students regardless of their abilities; it gives handicapped students the opportunities to blend socially and get involved in the business environment later. It helps parents of handicapped children to deal with them as normal children and get rid of negative feelings toward them. It modifies the ways members of the society in particular those in instructional and educational institutions behave toward handicapped students through recognizing their potential.

Saeed (2017) saw that the inclusion has benefits for the teachers themselves that they become more efficient in using teaching methodologies to all students. From this stand point, inclusion offers the handicapped two major opportunities: normalization and full functional participation. Also inclusion is beneficiary to normal students by giving them life lessons and dignity through respect. Also Fahmi (2016) sees that handicapped they are minority members of the society; this exposes them to so many social and economic pressures. It develops emotional manifestations as minorities usually struggle to maintain their entity.

Helal (2016) indicated that the successful process of the inclusion depends on some aspects such as environmental and material equipment and providing the necessary laws and legislation to guarantee the right of the handicapped through care, welfare, and preparing students, teachers and supervisors to accept the idea of inclusion, in addition to providing positive trends toward the handicapped. Al-Maaytah (2010) lists the positive factors that can lead to the acceptance of the idea of integrating handicapped students with normal students: increase in the educational level of individuals, the society's awareness of the causes and types of disability and how to prevent them and refute superstitious beliefs around them.

In this regard, Saqer (2004) emphasizes that attitudes can be changed by helping the individual change his or 
her response to a particular situation by replacing the old attitudes with the new direction. However, Mansi (2008) says that attitudes cannot be changed. However, studies have indicated that attitudes can be changed and modified by providing the individual with new information and influencing their emotional experience. Zahran (2005) argues that attitudes can be changed and modified by increasing the pro-direction effects and reducing the adverse effects of the attitudes; but if the pro-change and adverse effects of the change are equal, the balance will be stabilized and unchanged.

The importance of knowing the community's attitudes towards disability is the success of specialized programs in behavioral change, the preparation of counseling programs for persons with disabilities, and the development of positive attitudes towards disability and the continuous awareness of these positive concepts and trends. In this context, many studies have found a direct correlation between the attitudes of students and university staff and the entire university system towards supporting handicapped students, their success rate in higher education (Dy, 2005; Hong and Himmel, 2009).

Raley (2007) believes that new university students, if they do not feel affiliated with the institution after the first eight weeks of the study are likely to leave school. For example, Hagendorn (2005) noted that a number of handicapped students at university had postponed the study several times, some of them moved to smaller universities, and some others have left permanently because of factors related to discrimination against handicapped students, and others related to low achievement. Osegura and Rhee (2009) add that the inability of secondary schools to prepare handicapped students is one of the main reasons why they do not complete university education.

Amer (2016) added that universities have to form positive trends among students who enrolled in instructional and educational specializations toward the handicapped, since those students will be teachers in the near future, and the earlier they form these positive trends, the sooner their students will receive them through disciplines which focus on identifying the handicapped and their special needs. Lavonna (2018) added that the universities have to develop positive trends toward the handicapped students in order to contribute in producing psychologically healthy students and be open-minded to others regardless of abilities and capabilities.

In this domain Mohammad (2017) affirmed that the school has a crucial role in creating positive trends among students toward the handicapped though the educational curricula and the teacher's role in showing respect toward handicapped students. A number of studies have been conducted to identify attitudes towards individuals with disabilities, including the study of the attitudes of school students or university towards the handicapped or their Inclusion into the school environment, including the aim of studying the impact of training programs on changing the attitudes of students towards the handicapped. This study examines the attitudes of students towards handicapped with ordinary students in university environment.

Gerry et al. (2015) conducted a study aimed at investigating the attitudes of students at a Turkish university toward their fellow handicapped students. The researchers developed a scale that was answered by 1766 students studying at the Faculty of Education and Health. The results revealed that the majority of students agree that handicapped students face discrimination in Turkish society; however, they face now less discrimination ten years ago. The vast majority of students has no information about the laws, legislation and regulations governing handicapped persons and do not know that prejudice against handicapped persons is a crime punishable by Turkish law. In contrast, the results showed that students in rural and low-income environments had higher positive attitudes than other students in urban areas.

Al-Khawalda (2014) conducted a study aimed at identifying the attitudes of Hail University students towards handicapped people in Saudi Arabia and its relation to gender and academic majoring. The study sample consisted of 418 students. The study used attitude scale towards handicapped people. The results indicated that there were statistically significant differences in the gender variable in favor of female students and differences in the major variable in favor of the students of the Faculty of Education.

In this context, Bruder and Mogro-Wilson (2014) conducted a study aimed at understanding the attitudes, beliefs and information of students and staff at Northeastern University about handicapped and handicapped students. Overall, the researchers found that students and staff had positive attitudes towards dealing with handicapped students, but there was little and limited interaction with handicapped students. Faculty members and students reported that they feel embarrassed and are compassionate when dealing with handicapped students at the university; university staff have little knowledge of the needs and rights of handicapped students on campus.

Al- Mbaideen (2014) investigated the effectiveness of information program in changing the attitudes of university students towards handicapped persons in Jordan. The study sample consisted of 1824 students from the University of Jordan and the Hashemite University who listen to radio broadcasting. Empirical group consists of 912 students and control group of 912 students. The tools of the study were radio program and a measure of attitudes towards handicapped persons. The scale was applied to the sample of the study before the broadcast of the radio program and after its broadcast. The results indicated the effectiveness of the media program in changing the attitudes of university 
students particularly handicapped in favor of the experimental group, and the results indicated that there were statistically significant differences that are attributable to the program on the gender variable in favor of females, and statistically significant differences due to specialization variable in favor of faculty of sciences students.

Abdullah and Al-Dwairi (2013) study aimed at identifying the attitudes of Irbid National University students toward handicapped people based on their gender, specialization and level of study in Jordan. The sample of this study consisted of 93 male and female students. The results showed that there are positive attitudes toward handicapped people. And there were no statistically significant differences of the variables of gender, specialization and the level of study.

Al-Sarayra and Al-Sha'lan (2011) study aimed to identify the attitudes of the students of Mu'tah University toward the handicapped students based on their academic level and students' specialization. Sample of the study consisted of 210 students from the first and last year students in each major. The results indicate that there are statistically significant differences due to the level of the students in the last year and the existence of differences of statistical significance due to the specialization of the students in special education.

Other studies that examined the attitudes, beliefs and practices of university faculties towards handicapped students were conducted by Miri et al. (2008), who developed a scale that was answered by 192 faculty members from private university colleges. The results showed that female teachers compared with males counterparts were more willing to deal with and support handicapped students. They also had more information on disability and more likely to devote part of their time to this group of students. Overall, however, all teachers had positive expectations of the abilities of handicapped students and were willing to make simple compromises for such students. At the same time, faculty members need to receive additional information in order to provide appropriate teaching and examinations to handicapped students. Johnston and Dixon (2006) examined the impact of a training program on the development of the attitudes of the students of the second year nursing school represented by a sample of 379 students. The study showed significant differences between male and female students in this regard.

The study conducted by Rahal (2005) consisted of 204 students from the faculties of education, medical, and literature at Al-Baath University in Syria, and proper tools were developed for this purpose. The results indicate that there are moderate attitudes among the students of AlBaath University towards the handicapped. The results also indicate that there are statistical differences on the gender variable in favor of females. The results also indicate that there are no differences in the attitudes of the students towards handicapped students according to their specialization and those students who have relationship with handicapped people and those who do not have relationship with handicapped students.

Al-Batayneh and Al-Jarrah (2005) examined the nature of the attitudes of Yarmouk University students towards the handicapped and examined the relationship between these attitudes with several variables: gender, level of study, cumulative average, specialization and place of residence. The sample of the study consisted of 340 male and female first degree students of Yarmouk University in Jordan. The study tool was a questionnaire prepared by the researchers. Results of the study indicated that the attitudes of the Yarmouk University students were positive and the results showed that there are statistically significant differences in gender variable in favor of female students, academic level, fourth year students, majors and students of literary majors. The results also indicate that there are no statistically significant differences due to the variables of the cumulative rate and place of residence.

Palmer and Tervo (2002) conducted a study aimed at revealing the attitudes of students of the American and Canadian universities' medical school towards handicapped people and their relationship and gender variable. The study sample consisted of 90 students, 45 from US universities and 45 from Canadian universities. The results of the study showed that the attitudes of American and Canadian university students towards handicapped were positive. The results also showed statistically significant differences in gender variable in favor of females.

\section{The study problem}

Theoretical literature, studies and previous research have confirmed the right of handicapped students to be integrated in education within normal educational environment at all levels, but these studies indicated that the success of the inclusion of handicapped students with ordinary students in normal environment depends on several factors, including the issue of attitudes. Positive attitudes of individuals affect the success of the inclusion process and enhance the self-confidence of the handicapped, while negative attitudes of rejection, ridicule, avoidance, alienation or inferiority towards handicapped students will be a barrier to successful inclusion of handicapped students.

Previous studies on attitudes in the inclusion of handicapped students into the environment have mainly addressed the issue of attitudes from the inclusion of handicapped people in the school environment perspective; therefore this study is designed to detect attitudes in the World Islamic Sciences University students towards handicapped student's inclusion with normal students in university environment. Specifically, this study sought to answer the following 
two main questions:

Question 1: What are the attitudes of World Islamic Sciences University students towards handicapped students' inclusion with normal students at World Islamic Sciences University?

Question 2: Are there statistically significant differences at $p \leq 0.05$ in the attitudes of the students of the World Islamic University towards the inclusion of handicapped students with normal students at the World Islamic Sciences University based on gender, college level, marital status, and faculty?

\section{Objectives of the study}

The aim of this study is to identify the attitudes of the students of the World Islamic Sciences University towards the inclusion of handicapped students with ordinary students in the university environment. This study also revealed the differences in the attitudes of students towards the inclusion of handicapped students into the mainstream of normal students in the university environment based on different variables.

\section{The importance of the study}

The importance of this study stems from the theoretical part which deals with the subject that is considered to be scarce and crucial in educational studies, for the best knowledge of the researcher. The study investigates the attitudes of university students towards handicapped students' inclusion into the main stream. This stage is considered to be very important in the lives of handicapped students who are able to carry out life functions, acquire education like normal students, accept and enjoy the moral standards of high level of growth and maturity which are appropriate for this stage in their higher studies journey. This study will help us detect previous and subsequent attitudes to current stage as current attitudes are associated with their previous and subsequent attitudes towards the handicapped. These attitudes will not come from a vacuum. The importance of this study lies in its practical aspect which carries possibility of developing training programs to minimize negative attitudes - If any - towards the handicapped students' inclusion, as well as to overcome obstacles and difficulties which hinder their inclusion into the university environment- academically and socially.

\section{Procedural definitions}

\section{Attitude}

Is the degree obtained by the students on the study of the attitude scale of World Islamic sciences University students developed by the researcher. It is a tool utilized to measure normal students' attitudes towards handicapped students' inclusion in university environment.

\section{Students of the World Islamic Sciences University}

All male and female students officially enrolled in the bachelor program at the World Islamic Sciences University in Jordan during the first semester of the academic year 2017 to 2018 .

\section{Handicapped students' inclusion}

This process seeks the intergration of handicapped students who suffer from hearing, visual, and motor or speech impairments with normal students. The inclusion is both academic and social.

\section{MATERIALS AND METHODS}

The study aimed at identifying the World Islamic University students' attitude toward the inclusion of handicapped students within the university environment. To fulfil this aim the quantitative research method was applied using the descriptive survey; for being appropriate for the subject of the study. Abbiadat et al., (2016) affirmed that descriptive survey is a method in research; it is done by collecting data and information about certain phenomena or facts for the sake of identifying the situations surrounding them and knowing more about their points of strength and weakness.

\section{Study population}

The study population consisted of all the bachelor's degree students of the World Islamic Sciences University in Jordan and those who were registered officially during the first semester of the academic year 2017 to 2018 . Total number of the study's population reaches up to 3412 students distributed in nine faculties of which two colleges were established earlier this year. The current study took place in 2017, which are the two faculties of Fiqh Al- Hanafi and Fiqh Al-Shafei. Table 1 shows the distribution of the study population by university faculties.

\section{Study sample}

The sample of the study consists of 247 male and female students of the World Islamic Sciences University in Jordan in 2017 / 2018 academic year. The sample is equal to $7.24 \%$ to the population of the study. Participants were chosen randomly via stratified sampling approach: 139 male stud and 108 female students from all faculties of the university (Table 2).

\section{Study instrument}

The researcher developed a study tool after a preliminary reference to some theoretical literature and previous studies including that of Girli et al. (2015), Al - Khatib and al-Hadidi (2011), Murray et al. 
Table 1. Distribution of members of the study population by university's faculties.

\begin{tabular}{clc}
\hline S/N & College & Count \\
\hline 1 & Faculty of Sharia and Law & 687 \\
2 & Faculty of Arts and Sciences & 818 \\
3 & Faculty of Da'wa and Foundations of Religion & 447 \\
4 & Faculty of Educational Sciences & 307 \\
5 & Faculty of Fiqh Hanafi & 77 \\
6 & Faculty of Fiqh Shafei & 32 \\
7 & Faculty of Islamic Arts and Architecture & 28 \\
8 & Faculty of Business and Finance & 656 \\
9 & Faculty of Information technology & 360 \\
Total & Population of the Study & 3412 \\
\hline
\end{tabular}

Table 2. The distribution of the study sample according to the study variables.

\begin{tabular}{llcc}
\hline Variable & Variable classification & Frequency & Percentage \\
\hline \multirow{2}{*}{ Gender } & Male & 139 & 56.3 \\
& Female & 108 & 43.7 \\
& & & \\
\multirow{3}{*}{ Level of study } & First year and second year & 105 & 42.5 \\
& Third year and fourth year & 142 & 57.5 \\
\cline { 2 - 2 } Marital status & & \\
& Single & 190 & 76.9 \\
& Married & 57 & 23.1 \\
& & & \\
& Faculty of Sharia and Law & 44 & 17.8 \\
& Faculty of Arts and Sciences & 41 & 16.6 \\
& Faculty of Dawa and Foundation of Religion & 24 & 9.7 \\
& Faculty of Educational Sciences & 43 & 17.4 \\
& Faculty of Fiqh Al- Hanafi & 11 & 4.5 \\
& Faculty of Fiqh Al-Shafei & 9 & 3.6 \\
& Faculty of Arts and Islamic Architecture & 8 & 3.2 \\
& Faculty of Business and Finance & 40 & 16.2 \\
& Faculty of information technology & 27 & 11 \\
\hline
\end{tabular}

(2008), Nassar al-Hassan (2007), Obani and Doherty (2002), AlBatayneh and Jarrah (2005), Johnston and Dixon (2006) and Andersen (2005). This tool was designed to measure, in its initial form, two parts: First, demographic information of the variables of the study. The second consists of 29 items covering two dimensions: academic inclusion and social inclusion.

\section{Scale validity}

The scale validity is verified by the following:

\section{Content validity}

The scale was submitted in its initial form to a panel of ten faculty members who are experts in special education, counseling, and educational psychology. These referees expressed their opinion and remarks, reviewed and edited the language of the scale. Some items were rejected while others were modified until the number of items became 26 distributed equally to the two dimensions of the scale. Examples or rejected items: I believe it is impossible for me to marry my handicapped friend; I believe teachers deal with handicapped students with double standard.

Examples of modified items: I believe that handicapped students have the ability to pay attention, memorize, and recognize things as normal students do.

\section{Scale reliability}

To obtain scale consistency, researchers utilized two approaches:

Approach 1: Half-split method: consistency coefficient was computed through the use of Spearman-Brown equation; the 
Table 3. Evidence of consistency for the study scale.

\begin{tabular}{clc}
\hline Number & Dimension & Cronbach Alpha \\
\hline 1 & Academic Inclusion & 0.75 \\
2 & Social Inclusion & 0.77 \\
Total & & 0.79 \\
\hline
\end{tabular}

calculated coefficient was 0.863, which is an acceptable consistency coefficient.

Approach 2: internal consistency reliability through the use of Cronbach alpha coefficient; the value was 0.79 which is acceptable (Table 3).

Response means were classified into three categories (high, medium, low) according to the following equation: scale range/ number of categories $=(5-1) / 3=1.33$. The categories are as follow:

(1) $1-2.33$ Low.

(2) 2.34- 3.67 medium.

(3) 3.68- 5 High.

\section{Study variables}

Independent variables: This study included the following four independent variables:

(1) Gender: Male and female.

(2) Marital status: Single and Married.

(3) Level of study: First and second years and third and fourth years.

(4) Faculty: Faculty of Educational Sciences, Faculty of Arts and Sciences, Faculty of Business and Finance, Faculty of Information Technology, Faculty of Arts and Islamic Architecture, Faculty of Sharia and Law, Faculty of Religion Foundations, Faculty of Fiqh Al- Hanafi and Faculty of Fiqh Al- Shafei.

Dependent variable: Attitudes of students of the World Islamic Sciences University.

\section{Statistical analysis}

The researcher used the statistical package for social sciences (SPSS) to perform the necessary analyses and statistics for the collected data, adopting the five-point estimates as follows: very low, low, moderately low, high, and very high. The following values were given $1,2,3,4,5$, respectively. The scores were reversed with the negative items in the academic dimension where the negative items are $1,2,4,5,11,12$; negative items in the social dimension are 2, 3, 5, 6, 7 and 13. To answer the first question, means, standard deviations, rank and degree were used. To answer the second question, means, standard deviations, ( $T$ Test) (One way ANOVA) and Schiffe test were used for dimensional comparisons.

\section{RESULTS AND DISCUSSION}

This section includes an overview of the findings of this study by answering its questions as follows:

Question 1: What are the World Islamic Sciences
University students' attitudes towards handicapped students' inclusion with normal students at World Islamic Sciences University?

To answer this question, means and standard deviations, rank and degree of students' attitude in the World Islamic Sciences University towards handicapped students' inclusion with normal students at the World Islamic Sciences University in general and for each scope of study tool in particular were calculated (Table 4). Table 4 shows that World Islamic Sciences University students' attitude toward handicapped students' inclusion with normal students at the university was medium, with means of 3.32 and standard deviation of 0.32 ; area of the tool was medium; the mean was between 3.36 - 3.28. In the first rank came "academic Inclusion" with means of 3.36, and standard deviation of 0.35 . In the second and last rank came "social Inclusion" with means of 3.28 and standard deviation of 0.33 . As for the items of each scope, the results are shown as follows:

\section{Academic inclusion}

Means, standard deviations, rank and degree were calculated for World Islamic Sciences University students' attitude towards handicapped student's inclusion with normal students (Table 5). Table 5 reveals that World Islamic Sciences University students' attitudes towards the inclusion of handicapped students with normal students at World Islamic Sciences University in the field of academic inclusion was moderate, with means of 3.36 and standard deviation of 0.35 ; items of this scope came medium except for one item whose means ranged between 3.68-3.02. Item 12, which states that "Handicapped students need a lot of classroom adaptation" came in first place with means of 3.68 and a standard deviation of 0.87 ; it has high attitudes. In the second place came item 9 which states "A handicapped student can produce new and useful ideas that have an impact on their university environment" with means of 3.62 and standard deviation of 0.83 ; it has medium attitudes. Item 13 came before the last. It states that "Handicapped students can accomplish the tasks and duties required just like any other normal student"; it has mean of 3.10 and standard deviation of 0.95 ; it has medium attitudes. Item 2 came in the last place which states that "The capabilities and potential of handicapped students are limited"; it has mean of 3.02 and standard 
Table 4. Means, standard deviations, ranks and degree of World Islamic Sciences University students' attitude towards handicapped students inclusion with normal students of the university in descending order.

\begin{tabular}{llcccc}
\hline Number & Scope & Means & standard deviation & Rank & Attitude \\
\hline 1 & Academic Inclusion & 3.36 & 0.35 & 1 & Medium \\
2 & Social Inclusion & 3.28 & 0.33 & 2 & Medium \\
Total score & & 3.32 & 0.32 & - & Medium \\
\hline
\end{tabular}

Table 5. Means, standard deviations, rank and degree for students' attitudes World Islamic Sciences University towards handicapped students inclusion with ordinary students at the university for academic Inclusion items in descending order.

\begin{tabular}{clcccc}
\hline $\mathbf{S} / \mathbf{N}$ & Item & Means & $\begin{array}{c}\text { standard } \\
\text { deviation }\end{array}$ & Rank & Attitude \\
\hline 12 & Handicapped students need a lot of classroom adaptation & 3.68 & 0.87 & 1 & High \\
9 & $\begin{array}{l}\text { A handicapped student can produce new and useful ideas that have an } \\
\text { impact on their university environment }\end{array}$ & 3.62 & 0.83 & 2 & Medium \\
7 & Handicapped students have high motivation for the tasks required & 3.59 & 0.87 & 3 & Medium \\
3 & Many handicapped students can excel in their field of specialization & 3.52 & 0.93 & 4 & Medium \\
6 & $\begin{array}{l}\text { Handicapped students have creative talents and abilities like other ordinary } \\
\text { colleagues }\end{array}$ & 3.49 & 0.89 & 5 & Medium \\
1 & $\begin{array}{l}\text { Handicapped students pass the subjects they study because of the pity and } \\
\text { sympathy of the teachers due to their disability }\end{array}$ & 3.38 & 0.52 & 6 & Medium \\
11 & $\begin{array}{l}\text { Handicapped students show irrational illusions of academic failure } \\
5\end{array} \quad \begin{array}{l}\text { Some students with disabilities, such as audio or visual impairment, need } \\
\text { great help during university examinations, in order to succeed }\end{array}$ & 3.33 & 0.73 & 7 & Medium \\
10 & $\begin{array}{l}\text { Handicapped students seem to be fond of reading inside or outside the } \\
\text { university library }\end{array}$ & 3.31 & 0.81 & 8 & Medium \\
4 & $\begin{array}{l}\text { Some disabilities (audio, visual) need, for example, much of the lecture time } \\
\text { to understand what teachers are offering }\end{array}$ & 3.23 & 0.95 & 9 & Medium \\
8 & $\begin{array}{l}\text { Handicapped students have the ability to pay attention, remember, and } \\
\text { recognize information as ordinary students do }\end{array}$ & 3.19 & 0.92 & 10 & Medium \\
13 & $\begin{array}{l}\text { Handicapped students can accomplish tasks and duties required like other } \\
\text { ordinary students }\end{array}$ & 3.10 & 0.95 & 12 & Medium \\
2 & $\begin{array}{l}\text { The abilities and capabilities of handicapped students are limited } \\
\text { Academic lnclusion }\end{array}$ & 3.02 & 0.86 & 13 & Medium \\
\hline
\end{tabular}

deviation of 0.86 ; it has medium attitudes.

\section{The social inclusion}

Means, standard deviations, rank and degree were calculated for the World Islamic Sciences University students' attitude towards the inclusion of handicapped students with normal students at the World Islamic Sciences University. Items of this field are shown in Table 6.

Table 6 shows that the World Islamic Sciences University students' attitude towards handicapped students' inclusion with normal students' population for social inclusion scope was medium; it has means of 3.28 and standard deviation of 0.33 . Item of this scope was medium whereas its mean was between 2.81 to 3.61 .
Item 13 came in first place; it states "handicapped students constitute a burden to the university due to their inability to adapt to the university environment". It has mean of 3.61 and SD of 0.89 ; it has medium attitudes. Item 8 came in second place. It states that handicapped students are able to participate in university's activities; its mean is 3.56 and SD is 0.90 ; it has medium attitudes. The item before the last 4 states, "I prefer dealing with handicapped students"; item 12 states handicapped students have multiple skills that qualify them to adapt to the university; it has mean of 3.00 and two SDs of 0.83 and 0.78; it has medium attitudes. Item 7 came last: it states "my friendship with handicapped friend will be rejected by my family". It has mean of 2.81 and SD of 0.82 ; it has medium attitudes.

Results of this question revealed that World Islamic Sciences University students' attitude toward 
Table 6. Means, standard deviations, rank and degree of World Islamic Sciences University students' attitude towards the inclusion of handicapped students with normal students at the university were calculated in descending order.

\begin{tabular}{|c|c|c|c|c|c|}
\hline Number & Item & Means & standard deviation & Rank & Attitude \\
\hline 13 & $\begin{array}{l}\text { The handicapped student is a burden on the university } \\
\text { because it requires adaptation and modification of the } \\
\text { university environment }\end{array}$ & 3.61 & 0.89 & 1 & Medium \\
\hline 8 & $\begin{array}{l}\text { The handicapped student can participate in activities } \\
\text { organized by the university }\end{array}$ & 3.56 & 0.90 & 2 & Medium \\
\hline 3 & $\begin{array}{l}\text { There are psychological barriers between me and my } \\
\text { handicapped colleagues at the university }\end{array}$ & 3.53 & 0.91 & 3 & Medium \\
\hline 5 & $\begin{array}{l}\text { My handicapped colleague needs a lot of help so he can } \\
\text { move forward }\end{array}$ & 3.49 & 0.92 & 4 & Medium \\
\hline 1 & $\begin{array}{l}\text { The ability of the handicapped to serve the community and } \\
\text { others is great }\end{array}$ & 3.47 & 0.92 & 5 & Medium \\
\hline 10 & $\begin{array}{l}\text { Some handicapped students can build social relationships } \\
\text { with their peers and ordinary colleagues }\end{array}$ & 3.47 & 0.94 & 5 & Medium \\
\hline 2 & $\begin{array}{l}\text { My handicapped colleague needs my help always, making it a } \\
\text { burden on my mind }\end{array}$ & 3.19 & 0.90 & 7 & Medium \\
\hline 9 & $\begin{array}{l}\text { A handicapped student can perform university activities and } \\
\text { participate in university trips }\end{array}$ & 3.17 & 0.65 & 8 & Medium \\
\hline 6 & $\begin{array}{l}\text { My friendship with me handicapped friend faces ridicule by my } \\
\text { family. }\end{array}$ & 3.15 & 0.89 & 9 & Medium \\
\hline 11 & Handicapped students have the ability to express themselves & 3.15 & 0.88 & 9 & Medium \\
\hline 4 & I prefer dealing with handicapped students & 3.00 & 0.83 & 11 & Medium \\
\hline 12 & $\begin{array}{l}\text { Handicapped students have a lot of skills to adapt to the } \\
\text { university environment }\end{array}$ & 3.00 & 0.78 & 11 & Medium \\
\hline 7 & $\begin{array}{l}\text { My friendship with my handicapped colleague faces the } \\
\text { rejection by my family }\end{array}$ & 2.81 & 0.82 & 13 & Medium \\
\hline \multicolumn{2}{|c|}{ Social Inclusion } & 3.28 & 0.33 & - & Medium \\
\hline
\end{tabular}

handicapped students' inclusion with normal students were medium whether for total degree of the scale or for academic inclusion and social inclusion scopes. The researcher says the students' attitude is medium, that is not completely low and not too high. This means that students have cognitive, emotional, and behavioral awareness at medium level. All of these were gained by students' previous experiences which are neither sufficient nor bad. Thus, such students are in need of more study curriculum and training program in order to enhance their attitudes. In addition, students' medium attitudes are influenced by the society's attitudes at large. This means it is necessary to provide more awareness and guidance to the society at large; students' subeducation is influenced by several components such as the culture of the society at large.

These results are in line with the results of Abdullah and Dwairi (2012), Batayneh and Jarrah (2005) and Palmer and Tervo, (2002). These studies' results indicate that students' attitudes towards handicapped were positive, including that of Hassan (2017), Mohammad (2017), Helal (2016) and Amer (2016). However, this study's results differ from other studies such as Sarayra and Sha'lan (2011), which show that students' attitude towards handicapped were negative.
Question 2: Is there statistically significant variation at $p \leq$ 0.05 In World Islamic Sciences University based on gender, study level, marital status and college variables?

The answers to this question are as follows:

\section{Gender variable}

Means and SD for world Islamic Sciences University students' attitudes toward handicapped students' inclusion with normal student were calculated for gender variable. T- test was applied as shown in Table 7. Table 7 shows that there is statistically significant differences at $p$ $\leq 0.05$ for World Islamic Sciences University students' attitudes towards handicapped students' inclusion with normal students according to gender variable, based on computed $T$ - value which is 2.345 and at $\alpha=0.020$. Also, there are statistically significant variations at $p \leq 0.05$ in two scopes according to gender variable and based on computed T-value; they are 2.062- 2.345 at $\alpha \leq-0.020$ 0.040 variation in favor of male students because their mean is higher than that of female students. It is possible to have this result due to the higher number of male students in the university than that of female students; 
Table 7. Means and SD of World Islamic Sciences University students' attitudes towards handicapped students' inclusion according to gender variable.

\begin{tabular}{llccccc}
\hline Scope & Gender & Number & Means & Standard deviation & $\mathrm{t}$ - value & Level of significance $\mathbf{P}<$ \\
\hline \multirow{2}{*}{ Academic inclusion } & Male & 139 & 3.41 & 0.37 & 2.345 & 0.020 \\
& Female & 108 & 3.31 & 0.31 & & 0.040 \\
\multirow{5}{*}{ Social inclusion } & Male & 139 & 3.31 & 0.33 & 2.062 & \\
& Female & 108 & 3.23 & 0.32 & & 0.020 \\
\multirow{2}{*}{ Total degree } & & & & & \\
& Male & 139 & 3.36 & 0.33 & 2.345 & - \\
\hline
\end{tabular}

Table 8. Means and SD of world Islamic Sciences University students' attitude towards handicapped students' inclusion.

\begin{tabular}{|c|c|c|c|c|c|c|}
\hline Scope & Level & Size & Mean & standard deviation & t- value & Level of Significance \\
\hline \multirow{2}{*}{ Academic inclusior } & First year and second year & 105 & 3.31 & 0.33 & -2.082 & 0.038 \\
\hline & ${ }^{n}$ Third year and a fourth & 142 & 3.40 & 0.35 & - & - \\
\hline \multirow{2}{*}{ Social inclusion } & First year and second year & 105 & 3.28 & 0.30 & 0.241 & 0.809 \\
\hline & Third year and a fourth & 142 & 3.27 & 0.35 & & \\
\hline \multirow{2}{*}{ Total degree } & First year and second year & 105 & 3.30 & 0.30 & -1.007 & 0.315 \\
\hline & Third year and a fourth & 142 & 3.34 & 0.33 & - & - \\
\hline
\end{tabular}

thus, there is high level of male handicapped students' reaction and communication with normal female students in the university; this has led to an opportunity for normal male students to know much about handicapped students and their abilities, consequently their attitudes towards them has not been negative. The researcher was not able to find previous studies that agree with current study's results. Thus, it differs from that of Khawalda (2014), Rahal (2005), Johnston and Dixon (2006), Mbaideen (2014), Batayneh and Jarrah (2005), and palmer and Tervo (2002) in favor of female students. In addition, the current result differs from the results of Abdullah and Dwairi (2012); this one shows there are no differences in students' attitude based on gender variable

\section{Study level variable}

Means and SD of world Islamic Sciences University students' attitude towards handicapped students' inclusion with normal students at the World Islamic sciences University were calculated according to studies level variable; t-test was done (Table 8). Results as shown in Table 8 indicate that there are no statistically significant variations at $p \leq 0.05$ for World Islamic Sciences University students' attitude towards handicapped students' inclusion with normal students according to student's study level variable, based on (t) value $(1,007-)$ and alpha level of 0.315 . In addition, there are no statistically significant differences at $p \leq 0.05$ in social inclusion scope according to student's study level variable, based on t value (0.241) and $\alpha 0.809$; while there are differences in academic inclusion based on t value (2.082) and $\alpha=0.038$.

These difference are in favor of $3^{\text {rd }}$ and $4^{\text {th }}$ year students, because their mean is higher than that of $1^{\text {st }}$ and $2^{\text {nd }}$ year students. Results show that the differences in academic inclusion scope are in favor of $3^{\text {rd }}$ and $4^{\text {th }}$ year students. This was attributed to the impact of time factor, in which several courses were studied by both normal and handicapped students. Consequently, it shows a real picture of their academic abilities and achievement. In addition, first and second year students did not have the opportunity to study with handicapped students. Regarding social inclusion, there is no variation according to study level variable. It could be due to the role of society and family in forming handicapped picture to the students. This shows that humans are reactive either as influencer or are being influenced on by their surroundings. This result agrees with the studies of Sarayra and Sha'lan (2011), Batayneh and Jarrah (2005), Mohammad (2017) and Amer (2016). These studies point out to variations in favor of $3^{\text {rd }}$ and fourth year students. The current study has partial agreement with Abdullah and Dwairi (2012) study results which point that there are no differences based on students' study level variable. 
Table 9. Means and standard deviations of World Islamic Sciences University normal students' attitudes toward handicapped students inclusion according to marital status variable.

\begin{tabular}{llccccc}
\hline Scope & Marital status & Number & Means & Standard deviation & T- value & Level of significance \\
\hline \multirow{2}{*}{ Academic inclusion } & Single & 190 & 3.37 & 0.36 & 0.300 & 0.764 \\
& Married & 57 & 3.35 & 0.30 & - & - \\
\multirow{3}{*}{ Social inclusion } & Single & 190 & 3.27 & 0.35 & -0.345 & 0.730 \\
& Married & 57 & 3.29 & 0.27 & - & - \\
\multirow{3}{*}{ Total degree } & Single & 190 & 3.32 & $0: 34$ & -0.012 & 0.990 \\
& Married & 57 & 3.32 & $0: 26$ & - & - \\
\hline
\end{tabular}

\section{Marital status variable}

Means and standard deviations for World Islamic Sciences University normal students' attitudes toward handicapped students inclusion according to marital status variable were computed. T-test was also done as shown in Table 9. Table 9 shows that there are no statistically significant differences at $p \leq 0.05$ for World Islamic Sciences University students' attitudes toward handicapped students inclusion with normal students according to marital status variable based on calculated $t$ value of -0.012 and the level of significance at 0.990 . There are no statistically significant differences $p \leq 0.05$ for the two scopes, according to marital status variable, calculated $t$ value of $-0.345-0.300$ and level of significance between $0.730-0.764$. The researcher explains that this is not due to the students' marital status; whether they are married or single, they receive the same university education, society and family give them the same culture. This creates relatively similar attitudes. There are no previous studies that address students 'attitudes based on this variable due to lack of studies on university students' attitude towards the inclusion of handicapped in university environment. This is what distinguishes this study from others.

\section{Faculty variable}

The means and standard deviations of World Islamic Sciences University normal students' attitudes toward handicapped students' inclusion in World Islamic Sciences University according to faculty variable were computed. T-test was administered as shown in Table 10.

Table 10 shows apparent differences between the mean of World Islamic Sciences University normal students' attitudes toward handicapped students inclusion in World Islamic Sciences University according to faculty variable; whereas students from the faculties of Sharia and Islamic law and Art and Architecture have mean of 3.52, which is the highest, followed by students of Fiqh Al Shafei faculty ( 3.50 ), and Faculty of Arts and
Science ( $3: 47$ ). The mean of Figh Al- Hanafi (3.12) was the last. In order to determine whether the differences between means are statistically significant at $p \leq 0.05$, One way ANOVA analysis was applied.The results are shown in Table 11.

Table 11 shows there are statistically significant differences at $p \leq 0.05$ of World Islamic Sciences University students' attitude towards handicapped students' inclusion with normal students at the World Islamic Sciences University according to faculty variable based on $f$ value (8.558) and statistically significance at 0000 value. In addition, there are differences in the two scopes at $f$ value $(6.925-8.476)$ and 0000 value. In order to reveal the differences, Schiffe test was applied for dimensional comparisons, as shown in Table 12. It is seen in Table 12 that the difference in total degree was in favor of faculties of Sharia, Islamic Art and Architecture and Fiqh Al Shafei students compared to students of Fiqh Al- Hanafi, Educational Sciences, IT and Business and Finance Faculties; it is in favor of students of Art and Sciences faculty when compared with students of Fiqh Hanafi and Educational Sciences faculty. Those faculties' students have favorable results due to the following reasons: their students have studied academic courses that make them have positive attitudes, their environment contribute to the formation of positive attitudes in them, and these students interact with handicapped students and know their true potential thus their attitudes becomes more positive than their counterparts who have no dealing with disabled students.

The difference in academic inclusion was in favor of the faculties of Fiqh Al- Shafei and Arts, Sciences and Sharia when compared with the faculties of Figh Al Hanafi and Educational Science and Information Technology, and Business \& Finance; in favor of the students of the Faculty of Islamic Art and Architecture when compared with the faculties of Fiqh Al Hanafi and Educational Science; in favor of the students of the Faculty of Dawa and Foundation of Religion when compared with the faculties of students of Fiqh Al Hanafi. This result is attributed to the fact that college students with favorable results have had previous experiences that make them have positive attitudes towards 
Table 10. Means and standard deviations for World Islamic Sciences University normal students' attitudes toward handicapped students' inclusion in World Islamic Sciences University according to faculty variable.

\begin{tabular}{|c|c|c|c|c|}
\hline Dimensions & Faculty & Number & Means & standard deviation \\
\hline \multirow{10}{*}{ Academic Inclusion } & Sharia law & 44 & 3.53 & 0.36 \\
\hline & Arts and Science & 41 & 3.54 & 0.27 \\
\hline & Educational Science & 43 & 3.17 & 0.19 \\
\hline & Dawa and Foundations of Religion & 24 & 3.46 & 0.45 \\
\hline & Figh Al- Hanafi & 11 & 3.13 & 0.36 \\
\hline & Fiqh Al- Shafei & 9 & 3:55 & 0.16 \\
\hline & Islamic Art and Architecture & 8 & 3.50 & 0.18 \\
\hline & Business and Finance & 40 & $3: 23$ & 0.28 \\
\hline & Information technology & 27 & $3: 23$ & 0.37 \\
\hline & Total & 247 & 3.36 & 0.35 \\
\hline \multirow{10}{*}{ Social Inclusion } & Sharia law & 44 & 3.48 & $0: 26$ \\
\hline & Arts and Science & 41 & $3: 35$ & $0: 31$ \\
\hline & Educational Science & 43 & 3.13 & 0.20 \\
\hline & Dawa and Foundation of Religion & 24 & 3.27 & $0: 39$ \\
\hline & Fiqh Al- Hanafi & 11 & 3.12 & 0.30 \\
\hline & Fiqh Al- Shafei & 9 & 3.46 & 0.25 \\
\hline & Islamic Art and Architecture & 8 & 3:55 & 0.21 \\
\hline & Business and Finance & 40 & 3.16 & $0: 34$ \\
\hline & Information technology & 27 & 3.15 & 0.37 \\
\hline & Total & 247 & 3.28 & 0.33 \\
\hline \multirow{10}{*}{ Faculty degree } & Sharia law & 44 & 3.50 & 0.29 \\
\hline & Arts and Science & 41 & 3.45 & 0.27 \\
\hline & Educational Science & 43 & 3.15 & 0.14 \\
\hline & Dawa and Fundamentals of Religion & 24 & 3.37 & 0.41 \\
\hline & Fiqh Al- Hanafi & 11 & 3.13 & 0.32 \\
\hline & Fiqh Al- Shafei & 9 & 3.50 & 0.19 \\
\hline & Islamic Art and Architecture & 8 & 3.52 & 0.19 \\
\hline & Business \& Finance & 40 & 3.20 & 0.29 \\
\hline & Information technology & 27 & 3.19 & 0.36 \\
\hline & Total & 247 & 3.32 & 0.32 \\
\hline
\end{tabular}

Table 11. One-way analysis (ANOVA) was conducted to find significance differences of World Islamic Sciences University students' attitude towards handicapped students according to faculty variable.

\begin{tabular}{llccccc}
\hline Scope & Source of variation & Sum squares & $\begin{array}{c}\text { Degrees of } \\
\text { freedom }\end{array}$ & squares means & F-value & $\begin{array}{c}\text { level of } \\
\text { significance }\end{array}$ \\
\hline \multirow{3}{*}{ Academic inclusion } & Between groups & 6.556 & 8 & 0.819 & 8.467 & $0.000^{*}$ \\
& Within groups & 23.036 & 238 & 0.097 & - & - \\
& Overall & 29.592 & 246 & - & - & - \\
\multirow{5}{*}{ Social inclusion } & & & & & \\
& Between groups & 5.087 & 8 & 636 & 6.925 & $0.000^{*}$ \\
& Within groups & 21.855 & 238 & 0.092 & - & - \\
& Overall & 26.943 & 246 & - & - & - \\
Total degree & & & & & $0.000^{*}$ \\
& Between groups & 5.564 & 8 & 0.695 & 8.558 & - \\
& Within groups & 19.342 & 238 & 0.081 & - & - \\
\hline
\end{tabular}

*Statistically significant difference. 


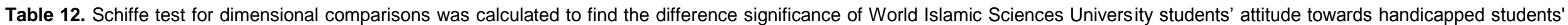
inclusion with normal students at World Islamic Sciences University according to faculty variable.

\begin{tabular}{|c|c|c|c|c|c|c|c|c|c|c|c|}
\hline Variable & Faculty & Means & Fiqh AI Shafei & Arts and Sciences & $\begin{array}{l}\text { Sharia } \\
\text { and law }\end{array}$ & $\begin{array}{l}\text { Islamic Arts and } \\
\text { Architecture }\end{array}$ & $\begin{array}{l}\text { Da'wa and foundation } \\
\text { of religion }\end{array}$ & $\begin{array}{l}\text { Business and } \\
\text { Finance }\end{array}$ & $\begin{array}{l}\text { Information } \\
\text { Technology }\end{array}$ & $\begin{array}{l}\text { Educational } \\
\text { Sciences }\end{array}$ & $\begin{array}{l}\text { Fiqh Al- } \\
\text { Hanafi }\end{array}$ \\
\hline & - & - & 3.55 & 3.54 & 3.53 & 3.50 & 3.46 & 3.23 & 3.23 & 3.17 & 3.13 \\
\hline \multirow{9}{*}{$\begin{array}{l}\text { Academic } \\
\text { Inclusion }\end{array}$} & Fiqh Al Shafei & 3.55 & - & - & - & - & - & $0.32^{*}$ & $0.32^{*}$ & $0.38^{*}$ & $0.42^{*}$ \\
\hline & Arts and Science & 3.54 & - & - & - & - & - & $0.31^{*}$ & $0.31^{*}$ & $0.37^{*}$ & $0.41^{*}$ \\
\hline & Sharia and law & 3.53 & - & - & - & - & - & $0.30^{*}$ & $0.30^{*}$ & $0.36^{*}$ & $0.40^{\star}$ \\
\hline & Islamic Arts and Architecture & 3.50 & - & - & - & - & - & - & - & $0.33^{*}$ & $0.37^{\star}$ \\
\hline & Da'wa and foundation of Religion & 3.46 & - & - & - & - & - & - & - & - & $0.33^{*}$ \\
\hline & Business \& Finance & 3.23 & - & - & - & - & - & - & - & - & - \\
\hline & Information Technology & 3.23 & - & - & - & - & - & - & - & - & - \\
\hline & Educational Science & 3.17 & - & - & - & - & - & - & - & - & \\
\hline & Fiqh Al- Hanafi & 3.13 & - & - & - & - & - & - & - & - & - \\
\hline \multirow{11}{*}{ Social Inclusion } & Faculty & Means & $\begin{array}{l}\text { Islamic Arts and } \\
\text { Architecture }\end{array}$ & Sharia and law & $\begin{array}{l}\text { Fiqh al } \\
\text { Shafei }\end{array}$ & $\begin{array}{l}\text { Arts and } \\
\text { Science }\end{array}$ & $\begin{array}{c}\text { Da'wa and foundation } \\
\text { of religion }\end{array}$ & $\begin{array}{l}\text { Business and } \\
\text { Finance }\end{array}$ & $\begin{array}{l}\text { Information } \\
\text { Technology }\end{array}$ & $\begin{array}{l}\text { Educational } \\
\text { Science }\end{array}$ & $\begin{array}{c}\text { Fiqh Al- } \\
\text { Hanafi }\end{array}$ \\
\hline & - & - & 3.55 & 3.48 & 3.46 & 3.35 & 3.27 & 3.16 & 3.15 & 3.13 & 3.12 \\
\hline & Islamic Arts and Architecture & 3.55 & - & - & - & - & - & $0.39^{*}$ & $0.40^{*}$ & $0.42^{*}$ & $0.43^{*}$ \\
\hline & Sharia and law & 3.48 & - & - & - & - & - & $0.32^{\star}$ & $0.33^{*}$ & $0.35^{*}$ & $0.36^{*}$ \\
\hline & Fiqh-Al Shafei & 3.46 & - & - & - & & - & $0.30^{*}$ & $0.31^{*}$ & $0.33^{*}$ & $0.34^{*}$ \\
\hline & Arts and Science & 3.35 & - & - & - & - & - & - & - & - & - \\
\hline & Da'wa and Foundation of Religion & 3.27 & - & - & - & - & - & - & - & - & - \\
\hline & Business \& Finance & 3.16 & - & - & - & - & - & - & - & - & - \\
\hline & Information Technology & 3.15 & - & - & - & - & - & - & - & - & - \\
\hline & Educational Science & 3.13 & - & - & - & - & - & - & - & - & - \\
\hline & Fiqh Al- Hanafi & 3.12 & - & - & - & - & - & - & - & - & - \\
\hline \multirow{9}{*}{ Total score } & Faculty & Means & Sharia and law & $\begin{array}{l}\text { Islamic Arts and } \\
\text { Architecture }\end{array}$ & $\begin{array}{l}\text { Fiqh al } \\
\text { Shafei }\end{array}$ & $\begin{array}{l}\text { Arts and } \\
\text { Science }\end{array}$ & $\begin{array}{c}\text { Da'wa and foundation } \\
\text { of religion }\end{array}$ & $\begin{array}{l}\text { Business and } \\
\text { Finance }\end{array}$ & $\begin{array}{l}\text { Information } \\
\text { Technology }\end{array}$ & $\begin{array}{l}\text { Educational } \\
\text { Science }\end{array}$ & $\begin{array}{c}\text { Fiqh Al- } \\
\text { Hanafi }\end{array}$ \\
\hline & - & - & 3.52 & 3.52 & 3.50 & 3.47 & 3.38 & 3.20 & 3.19 & 3.16 & 3.12 \\
\hline & Sharia and law & 3.52 & - & - & - & - & - & $0.32^{*}$ & $0.33^{*}$ & $0.36^{*}$ & $0.40^{*}$ \\
\hline & Islamic Arts and Architecture & 3.52 & - & - & - & - & - & $0.32^{*}$ & $0.33^{*}$ & $0.36^{*}$ & $0.40^{*}$ \\
\hline & Figh Al Shafei & 3.50 & - & - & - & - & - & $0.30^{*}$ & $0.31^{*}$ & $0.34^{*}$ & $0.38^{*}$ \\
\hline & Arts and Science & 3.47 & - & - & - & - & - & - & - & $0.31^{*}$ & $0.35^{\star}$ \\
\hline & Da'wa and foundation of religion & 3.38 & - & - & - & - & - & - & - & - & - \\
\hline & Business and Finance & 3.20 & - & - & - & - & - & - & - & - & - \\
\hline & Information Technology & 3.19 & - & - & - & - & - & - & - & - & - \\
\hline
\end{tabular}


Table 12. Contd.

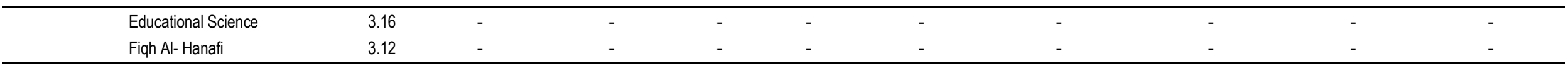

Differences are statistically significant.

handicapped and also they have handicapped relatives or siblings and therefore have great sympathy for handicapped people.

The difference in social inclusion was in favor of the faculties of Islamic Art and Architecture and Law and Figh Al- Shafei when compared with faculties of Fiqh Al- Hanafi and Educational Sciences and Information Technology and Business and Finance. The students with good results have made friendship with handicapped people before now, have prior knowledge about handicapped students and have tolerant attitude towards them.

\section{RECOMMENDATIONS}

Based on the results of the study, the researcher recommends the following:

(1) Holding seminars and workshops especially in defining handicapped persons, investing in universities' broadcasts, and strengthening the role of universities in providing facilities and proper logistics to teach handicapped students.

\section{(2) Adoption of compulsory courses on} handicapped individuals by all university students.

\section{CONFLICT OF INTERESTS}

The authors have not declared any conflict of interests.

\section{REFERENCES}

Abbiadat T, Adas A, Abd Al Haq Kayed (2016). The scientific Research. (18th ED). Amman: Dar al-Fiker Publishing

Abdullah AymanYahya, Al- Dwairi Fakri (2013). The Attitudes of Irbid National University Students Towards individuals Handicapped and the Impact of a Training Program based on Islamic Education. Journal of Balqa Research and Studies 16(2):107-156.

Al Khatib Jamal, Al Hadidi Mona (2011). Curricula and Teaching Methods in Special Education . (2nd Ed). Amman: Dar al-Fiker Publishing.

Al- Mbaideen, Lana Mohammed (2014). The Effectiveness of an Informative Program in Changing the Attitudes of University Students Towards People Handicapped in Jordan. An unpublished Ph.D thesis. The World Islamic Sciences University, Amman, Jordan.

Al Makhzoumi Nasser (2001). The Attitudes of Teachers in southern Jordan Region Towards the Arabic language and its Teaching in the light of their Experience and Gender. Damascus University Journal, 17(1):124-151.

Al-Rahal D (2005). The Attitudes of Students of some Faculties of the Baath University Towards Handicapped and its Relationship with some Variables . Ba'ath University Journal 27(7):213-237.

Amer S (2016). Psychology. Dar -Al massira: Amman

Andersen MB (2005). Sport Psychology in Practice. Champaign, IL: Human Kinetics.

Baker KQ, Boland K, Nowik CM (2012).A Campus Survey of Faculty and Student Perceptions of Persons with Disabilities. Journal of Postsecondary Education and Disability 25(4):309-329.

Batayneh O, Jarrah A-N (2005). Yarmouk University Students' Attitudes Towards the Handicapped and their Relationship with some Variables. Yarmouk Research Series Humanities and Social Sciences 21(3):459-480

Bruder MB, Mogro-Wilson C (2014).Student and faculty awareness and attitudes about students with disabilities. Review of Disability Studies: An International Journal 6(2).

Cook L, Rumrill PD, Tankersley M (2009). Priorities and understanding of faculty members regarding college students with disabilities. International Journal of Teaching and Learning in Higher Education 21(1):84-96.

Cooper J, Haney J (1999). Classroom Teaching Skills. (6th ed). Houghton Mifflin, USA P 64

Dy, C. L. (2005). Faculty knowledge about disability laws and their attitudes toward students with disabilities at Northern Virginia Community College (D.A.).George Mason University, Ann Arbor. Retrieved from Dissertations \& Theses @ George Mason University - WRLC. (305364768) Theses @ George Mason University - WRLC. (305364768)
Fahmi E (2016). Modern Education .Dar -Al fiker: Amman.

Fahmi E (2016). Modern Education .Dar -Al fiker: Amman.
Girli A, Sari HY, Kirkim G, Narin S (2015). University students' attitudes towards disability and their views on discrimination. International Journal of Developmental Disabilities 2047387715Y-0000000008

Hagendorn LS (2005). How to define retention: A new look at an old problem. In: A. Seidman (Ed.), College student retention: formula for student success (Chap. 4:89-105). American Council on Education and Praeger Publishers.

Hassan S (2017).Trends toward the Handicapped. Dar -Al fiker: Amman.

Healey M, Bradley A, Fuller M, Hall T (2006).Listening to students: the experiences of disabled students of learning at university. Towards Inclusive Learning in Higher Education: Developing Curricula for Disabled Students. London: Routledge Falmer pp. 32-43.

Helal Y (2016).Introduction to Psychology.2nd edition .Dar -Al fiker: Amman.

Hong BSS, Himmel J (2009). Faculty attitudes and perceptions toward collegestudents with disabilities. College Quarterly 12(3):6-16.

Johnston Ch, Dixon R (2006).Nursing Students Attitudes toward People with Disabilities: Can They Be Changed. Faculty of Nursing, University of Sydney.

Khawalda M (2014). Hail University Students' Attitudes Towards Integrating People with Special Needs in the light of some variables. Al-Quds Journal - Open University of Researches and Studies, Issue No. 37(2) - October 2015 pp. 313-328.

Lavonna L Lovern (2018). Fostering a Climate of Inclusion in the College Classroom. New York: Palgrave macmillan.

Al-Maaytah, Khalil (2010). Social Psychology. (3rd Ed). Amman: Dar Al fiker for Publishing. 
Maggiolini S, Molteni P (2013). University and Disability: An Italian Experience of Inclusion. AHEAD Association on 26(3):249.

Mansi M (2008). Educational Psychology for teachers. Cairo: Dar Al Ma'refa Al Jam 'yah for Publishing.

Mohammad A (2017). Educational Inclusion. 2nd Edition. Dar -Al massira: Amman.

Abdullah MF (2007). The Attitudes of Sports Education Department's Students Towards their Field at the University of Bahrain, Journal of Education 84:53-97.

Murray C, Wren CT, Keys C (2008). University faculty perceptions of students with learning disabilities: Correlates and group differences. Learning Disability Quarterly 31(2):95-113.

Nassar Y, al-Hasan S (2007). The Attitudes of Students of the Department of Early Childhood in the Hashemite University Towards their Field and its Relationship with their Gender and their level of academic Achievement. The Jordanian Journal of Educational Science 3(4):397-408

Obani T, Doherty J (2002). A study of some factors influencing attitudes to teaching the handicapped among Nigerian student teachers. International Journal of Education Development 4(4):285-291.

Osegura L, Rhee BS (2009). The influence of institutional retention climates on student persistence to degree completion: A multilevel approach. Research in Higher Education 50:546-569.

Palmer GRP, Tervo R (2002). An Examination of Attitudes toward Disabilities Among College Students: Tural and Urban Differences. Journal of Rural Community Psychology 31(3):20-39.

Raley $Y$ (2007). Why we quit. Scientific American Mind, August/September pp. 75-79.
Saeed H (2017). The issue of Inclusion .Dar -Al Yazori : Amman.

Saqer M (2004). A Proposed Program within the Sciences Curriculum for the Development of Attitudes against Smoking and Drug use. Educational Journal 18(71):56-87.

Sarayra R, Al- Sha'lan M (2011). Attitudes of Mu'tah University Students Towards the Handicapped. Journal of Mu'tah Research and Studies, 26(1):67-96.

Sultan M (2003). Organizational Behavior. Alexandria: Dar Al jame`a al jadidah.

Wade C, Tavris C (2005). Invitation to Psychology. (3rd ed), Boston MA: Addison- Wesley.

Zahran HAS (2005). Social Psychology. Cairo: Alam alkutob for Publishing. 